\title{
Systematic Review of Percutaneous Lumbar Mechanical Disc Decompression Utilizing Dekompressor ${ }^{\circledR}$
}

Vijay Singh, MD¹, Ramsin M. Benyamin, MD², Sukdeb Datta, MD³, Frank J. Falco, MD, Standiford Helm II, MD, and Laxmaiah Manchikanti, MD ${ }^{6}$

From: ${ }^{1}$ Pain Diagnostics Associates, Niagara, Wl; ${ }^{2}$ Millennium

Pain Center, Bloomington, IL; ${ }^{3}$ Vanderbilt University Medical

Center, Nashville, TN; ${ }^{\mathrm{Mid}}$ Atlantic Spine \& Pain Specialists, Newark, DE; ${ }^{5}$ Pacific Coast Pain Management Center, Laguna Hills, CA; and ${ }^{6}$ Pain Management Center of Paducah, Paducah, KY.

Dr. Singh is Medical Director of Pain Diagnostics Associates, Niagara, WI. Dr. Benyamin is the Medical Director, Millennium Pain Center, Bloomington, IL, and Clinical Assistant Professor of Surgery, College of Medicine, University of Illinois, Urbana-Champaign, IL.

Dr. Datta is Director, Vanderbilt University Interventional Pain Program, Associate Professor, Dept. of Anesthesiology, Vanderbilt University Medical Center, Nashville,

TN. Dr. Falco is Medical Director of Mid Atlantic Spine \& Pain Physicians of Newark, DE, Director, Pain Medicine Fellowship, Temple University Hospital, Philadelphia, PA, and Clinical Assistant Professor, Temple University Medical School,

Philadelphia, PA. Dr. Helm is Medical Director, Pacific Coast Pain Management Center, Laguna Hills,

CA. Dr. Manchikanti is Medical Director of the Pain Management Center of Paducah, Paducah, KY.

Address correspondence: Vijay Singh, MD

W809o Millie Hill Estates Dr. Iron Mountain, MI 49801-6722

E-mail:vj@wmpnet.net

Disclaimer: There was no external funding in the preparation of this manuscript. Conflict of interest: None.

Manuscript received: 02/13/2009 Accepted for publication: 04/27/2009

Free full manuscript: www.painphysicianjournal.com
Background: In recent years, a number of minimally invasive nuclear decompression techniques for lumbar disc prolapse, protrusion, and/or herniation have been introduced, including the Dekompressor ${ }^{\circledR}$ a device utilizing an Archimedes screw. The primary goal of the surgical treatment of nerve root compression from a disc protrusion continues to be the relief of compression by removing the herniated nuclear material with open discectomy. However, poor results have been reported for contained disc herniations with open surgical interventions. The results with several alternative techniques including the Dekompressor, automated percutaneous discectomy, and laser discectomy have been described, but are not convincing. There is a paucity of evidence for all decompression techniques.

Study Design: A systematic review of the mechanical disc decompression with Dekompressor literature.

Objective: The objective of this systematic review is to evaluate the clinical effectiveness of the Dekompressor, a high rotation per minute device utilizing an Archimedes screw, used in mechanical lumbar disc decompression.

Methods: The literature search was conducted utilizing a comprehensive strategy for mechanical disc decompression utilizing the Dekompressor. A literature search was conducted using only English language literature in a comprehensive search of databases including PubMed, EMBASE, the Cochrane Library, along with systematic reviews, and cross-references from reviews, systematic reviews, and individual articles. The quality of the manuscripts included was evaluated according to Cochrane review criteria for randomized controlled trials (RCTs), and for observational studies with the criteria developed by the Agency for Healthcare Research and Quality (AHRQ).

The level of evidence developed by the United States Preventive Services Task Force (USPSTF) was utilized in this review. The evidence was classified as Level I, II, or III with 3 subcategories in Level II for a total of 5 levels of evidence.

Outcome Measures: Pain relief was the primary outcome measure. Other outcome measures were functional improvement, improvement of psychological status, opioid intake, and return to work.

Short-term effectiveness was defined as one year or less, whereas, long-term effectiveness was defined as greater than one year.

Results: Based on USPSTF criteria the indicated level of evidence for the mechanical high RPM device or Dekompressor is Level III for short- and long-term relief.

Limitations: Lack of literature, both randomized and observational.

Conclusion: This systematic review illustrates Level III evidence for mechanical percutaneous disc decompression procedures with the high RPM device or Dekompressor.

Key words: Intervertebral disc disease, chronic low back pain, mechanical disc decompression, disc protrusion, disc extrusion, radiculitis, and mechanical high RPM device, Dekompressor

Pain Physician 2009; 12:589-599 
umbar discogenic radicular pain secondary to lumbar disc prolapse, protrusion, or herniation accounts for less than $5 \%$ of low back problems. However, disc abnormalities constitute the most common causes of nerve root pain (1). Lumbar discectomies are often performed to decompress the nerve root and alleviate radicular pain in cases of failed conservative therapy. The primary goal of surgical treatment is the relief of nerve root compression by removing the herniated nuclear material and the primary modality of treatment has been open discectomy. However, the specific pathology often determines the most suitable procedure. Extruded and sequestered disc herniations may require more invasive procedures to retrieve the disc material, whereas disc protrusions are potentially more amenable to minimally invasive percutaneous procedures. Mixter and Barr (2) reported on the first open surgical treatment for rupture of the intervertebral disc in 1934. Within a few years, less invasive procedures started appearing with a description by Love in 1939 (3). In 1959, Smith introduced chemonucleolysis by enzymatic dissolution of the nucleus pulposus with chymopapain derived from the papaya fruit as an alternative less invasive means of decompressing the herniated disc (4). Hijikata (5) described manual percutaneous lumbar discectomy in the 1970s. Subsequently, in 1985, Onik et al (6) described automated percutaneous lumbar discectomy (APLD), a minimally invasive method for mechanically treating contained disc herniations. The Dekompressor system was introduced based on the philosophy of APLD (7-9).

Multiple alternative techniques to open surgical discectomy have been introduced including microdiscectomy, chemonucleolysis, APLD, manual percutaneous discectomy, laser discectomy, nucleoplasty, and the Dekompressor a high rotation per minute device $(10,11)$. While multiple claims have been made from the literature over the last 30 years that all of these alternative procedures can produce satisfactory results with smaller wounds and fewer serious complications, these claims continue to remain either unproven or controversial. Even then, there continues to be an increase in the utilization of intradiscal therapies and percutaneous mechanical disc decompression procedures (11-21). The specific pathology often determines the most suitable procedure. Few studies have attempted to correlate outcomes of microdiscectomy for lumbar disc herniations with the specific type or level of disc herniation (22-24). Less satisfactory out- comes with smaller lumbar disc herniations have been identified, demonstrating that surgical outcomes are better predicted by herniation size and type than by patient age, gender, or workers' compensation status (24). Lumbar disc herniation types have been described based on annular competence and the presence of sequestered or extruded disc fragment.

Carragee et al (23) reported the outcome of single level lumbar discectomies in 187 consecutive patients with a mean age of 37.5 years. They showed poorer surgical outcomes in patients with massive annular defects and in those with an intact annulus and no identifiable fragment. Carragee et al showed the worst results with reherniation and improvement in patients with contained disc herniations. Dewing et al (22) in an evaluation of 197 consecutive single level lumbar microdiscectomies performed by a single surgeon showed that patients with sequestered or extruded lumbar disc herniations had significantly better outcomes than did those with contained herniations. Patients with contained disc herniations, a predominance of back pain, on restricted duty and smoking are expected to have poorer outcomes and decreased return to duty rates. They concluded that in a carefully screened patients, lumbar microdiscectomy for symptomatic disc herniation results in an overall high success rate, patient satisfaction, and return to physically demanding activities.

The Dekompressor ${ }^{\circledR}$ system is a single-use probe intended for percutaneous discectomies under fluoroscopic imaging. The device removes a predetermined amount of disc material from the herniated disc, reducing pressure in the disc and the surrounding area. Using a cannula placement similar to that used for a standard discography, less pertinent scarring and less postoperative fibrosis may be expected with this device (9). The Dekompressor has been described as a minimally invasive technique with advantages over other techniques (7). Alo et al (7) have noted that complications from chymopapain are dose dependent and can lead to fatal anaphylaxis, cartilaginous endplate damage, and hemorrhage $(25,26)$. They also described that automated and manual nucleotomy has been difficult to confirm (27), and one author suggested that positive outcomes may be equivalent to spontaneous resolution of symptoms (28). However, APLD has been presented with extensive experience and also numerous outcome studies with significant evidence (29). The proponents of the Dekompressor also note that laser discectomy may be associated 
with endplate injury and has enjoyed less success than chemonucleolysis in randomized studies (30). However, the present evidence in contrast to these statements shows significant effectiveness of laser discectomy (31). Proponents also state that nucleoplasty dissociates tissue with coblation and thus does not allow for the physical extraction of formed disc material (32). However, this criticism also has been questioned by others (33). In spite of all the limitations, all minimally invasive techniques share the same disc access approach as applied to discography and report low complication rates.

Gibson and Waddell (1) in a Cochrane Collaboration systematic review presented the results of discectomy. This review indicated that other than the traditional open surgical discectomy the place is unresolved for the forms of discectomy. They concluded that there is considerable evidence that surgical discectomy provides effective clinical relief for carefully selected patients with sciatica due to lumbar disc prolapse that fails to resolve with conservative management: however, they also concluded that all alternative techniques should be regarded as research techniques until further evidence is made available.

The Centers for Medicare and Medicaid Services (CMS) has recently issued a non-certification for intradiscal procedures (12). CMS refers to multiple procedures collectively as thermal intradiscal procedures, including intradiscal electrothermal thermal therapy (IDET), percutaneous intradiscal radiofrequency thermocoagulation (PIRFT), radiofrequency annuloplasty, intradiscal biacuplasty (IDB), percutaneous or (plasma) disc decompression (PDD), and coblation or targeted disc decompression (TDD).

This systematic review is undertaken to evaluate the current evidence of percutaneous lumbar mechanical disc decompression focusing on the Dekompressor, a mechanical high RPM device.

\section{Methods}

\section{Literature Search}

Databases reviewed were PubMed, EMBASE, the Cochrane Library, and the Database of Reviews of Effectiveness (DARE). Bibliographies of reviewed papers were also examined. In addition, authors known to be active in the field were contacted. The time frame covered was 1966 to January 2009.

\section{Inclusion criteria were:}

1. Lumbar disc related pain of at least 3 months duration,

2. Treatment with mechanical high RPM device or Dekompressor.

3. Minimum of 12-month follow-up.

4. At least 50 patients included in observational studies.

Search terms included intervertebral disc, degenerative disc disease, disc herniation, disc protrusion, disc extrusion, disc prolapse, disc displacement, radiculitis, Dekompressor a mechanical high RPM device, and mechanical disc decompression.

Only articles in English or with English abstracts, systematic reviews, randomized controlled trials (RCTs), and observational studies were reviewed by two reviewers. Discrepancies in rating were resolved by adjudication by a third reviewer. If there was a conflict of interest with the reviewed manuscripts such as authorship or any other type of conflict, the involved authors did not review the manuscripts for quality assessment, clinical relevance, evidence synthesis, or grading of evidence.

\section{Methodologic Quality Assessment}

The method of quality assessment was a function of the type of study. The Cochrane review criteria were used for RCTs (34). Assessment of study quality for observational studies was done according to the Agency for Healthcare Research and Quality (AHRQ) criteria (35). Both the RCTs and observational forms provide a maximum of 100 points; only studies with scores of over 50 points were included in this review. Consensus-based weighted scoring developed by the guidelines committee of the American Society of Interventional Pain Physicians (ASIPP) was utilized in this review. The same scoring system has been used in multiple evaluations $(29,31,33,36-49)$.

Both RCTs and observational studies were included in the review to improve generalizability and application of the percutaneous mechanical disc decompression (50-54).

\section{Outcome Measures}

Pain relief was the primary outcome measure. Other outcome measures were functional improvement, improvement of psychological status, and return to work.

A decrease of either 2 points or $30 \%$ of pain scores provides a useful benchmark of clinical importance to 
assess effectiveness $(55,56)$. Similarly, a $10 \%$ improvement in functioning outcomes provides an accepted benchmark of clinically useful benefit (57). However, in interventional pain management settings, a significant improvement has been defined as $\mathbf{5 0 \%}$ or more relief, whereas significant improvement in disability has been defined as a $40 \%$ or more decrease in disability scores in multiple publications (52-54,58-64).

Significant pain relief $(\geq 50 \%)$ of short-term $(\leq 12$ months) and long-term ( $>12$ months) was the primary outcome measure. Secondary outcomes included functional or psychological improvement, improvement in work status, and complications.

\section{Analysis of Evidence}

Level of evidence was determined based on the United States Preventive Services Task Force (USPSTF) criteria using 5 levels of evidence, ranging from Level I to III with 3 subcategories in Level II, as illustrated in Table 1 (65).

\section{Recommendations}

Recommendations for effectiveness were made according to Guyatt et al's criteria (66) (Table 2).

Table 1. Quality of evidence developed by USPSTF.

\begin{tabular}{|c|l||}
\hline I: & Evidence obtained from at least one properly randomized controlled trial \\
\hline II-1: & Evidence obtained from well-designed controlled trials without randomization \\
\hline II-2: & $\begin{array}{l}\text { Evidence obtained from well-designed cohort or case-control analytic studies, preferably from more than one center or research } \\
\text { group }\end{array}$ \\
\hline II-3: & $\begin{array}{l}\text { Evidence obtained from multiple time series with or without the intervention. Dramatic results in uncontrolled experiments (such } \\
\text { as the results of the introduction of penicillin treatment in the 1940s) could also be regarded as this type of evidence }\end{array}$ \\
\hline III: & Opinions of respected authorities, based on clinical experience descriptive studies and case reports or reports of expert committees \\
\hline
\end{tabular}

Adapted from the U.S. Preventive Services Task Force (USPSTF) (65).

Table 2. Grading recommendations.

\begin{tabular}{|c|c|c|c|}
\hline $\begin{array}{l}\text { Grade of Recommendation/ } \\
\text { Description }\end{array}$ & $\begin{array}{l}\text { Benefit vs Risk and } \\
\text { Burdens }\end{array}$ & $\begin{array}{l}\text { Methodological Quality of } \\
\text { Supporting Evidence }\end{array}$ & Implications \\
\hline $\begin{array}{l}1 \mathrm{~A} / \text { strong recommendation, } \\
\text { high-quality evidence }\end{array}$ & $\begin{array}{l}\text { Benefits clearly out- } \\
\text { weigh risk and burdens, } \\
\text { or vice versa }\end{array}$ & $\begin{array}{l}\text { RCTs without important limitations or } \\
\text { overwhelming evidence from observa- } \\
\text { tional studies }\end{array}$ & $\begin{array}{l}\text { Strong recommendation, can apply } \\
\text { to most patients in most circum- } \\
\text { stances without reservation }\end{array}$ \\
\hline $\begin{array}{l}1 \mathrm{~B} / \text { strong recommendation, } \\
\text { moderate quality evidence }\end{array}$ & $\begin{array}{l}\text { Benefits clearly out- } \\
\text { weigh risk and burdens, } \\
\text { or vice versa }\end{array}$ & $\begin{array}{l}\text { RCTs with important limitations (incon- } \\
\text { sistent results, methodological flaws, indi- } \\
\text { rect, or imprecise) or exceptionally strong } \\
\text { evidence from observational studies }\end{array}$ & $\begin{array}{l}\text { Strong recommendation, can apply } \\
\text { to most patients in most circum- } \\
\text { stances without reservation }\end{array}$ \\
\hline $\begin{array}{l}\text { 1C/strong recommendation, } \\
\text { low-quality or very low-quality } \\
\text { evidence }\end{array}$ & $\begin{array}{l}\text { Benefits clearly out- } \\
\text { weigh risk and burdens, } \\
\text { or vice versa }\end{array}$ & Observational studies or case series & $\begin{array}{l}\text { Strong recommendation but may } \\
\text { change when higher quality evidence } \\
\text { becomes available }\end{array}$ \\
\hline $\begin{array}{l}\text { 2A/weak recommendation, high- } \\
\text { quality evidence }\end{array}$ & $\begin{array}{l}\text { Benefits closely bal- } \\
\text { anced with risks and } \\
\text { burden }\end{array}$ & $\begin{array}{l}\text { RCTs without important limitations or } \\
\text { overwhelming evidence from observa- } \\
\text { tional studies }\end{array}$ & $\begin{array}{l}\text { Weak recommendation, best action } \\
\text { may differ depending on circum- } \\
\text { stances or patients' or societal values }\end{array}$ \\
\hline $\begin{array}{l}2 \mathrm{~B} / \text { weak recommendation, mod- } \\
\text { erate-quality evidence }\end{array}$ & $\begin{array}{l}\text { Benefits closely bal- } \\
\text { anced with risks and } \\
\text { burden }\end{array}$ & $\begin{array}{l}\text { RCTs with important limitations (incon- } \\
\text { sistent results, methodological flaws, indi- } \\
\text { rect, or imprecise) or exceptionally strong } \\
\text { evidence from observational studies }\end{array}$ & $\begin{array}{l}\text { Weak recommendation, best action } \\
\text { may differ depending on circum- } \\
\text { stances or patients' or societal values }\end{array}$ \\
\hline $\begin{array}{l}\text { 2C/weak recommendation, } \\
\text { low-quality or very low-quality } \\
\text { evidence }\end{array}$ & $\begin{array}{l}\text { Uncertainty in the esti- } \\
\text { mates of benefits, risks, } \\
\text { and burden; benefits, } \\
\text { risk, and burden may } \\
\text { be closely balanced }\end{array}$ & Observational studies or case series & $\begin{array}{l}\text { Very weak recommendations; } \\
\text { other alternatives may be equally } \\
\text { reasonable }\end{array}$ \\
\hline
\end{tabular}

Adapted from Guyatt $\mathrm{G}$ et al. Grading strength of recommendations and quality of evidence in clinical guidelines. Report from an American College of Chest Physicians task force. Chest 2006; 129:174-181 (66). 


\section{Results}

The results of literature search for mechanical disc decompression procedures are illustrated in Fig. 1. A total of 4 articles $(7-9,67)$ were located in the literature search.

\section{Methodologic Quality Assessment}

There were no RCTs identified; however, 4 studies were identified utilizing the Dekompressor. Of these, a study by Alo et al was the final report of a preliminary study by the same authors (7). Amoretti et al (67)

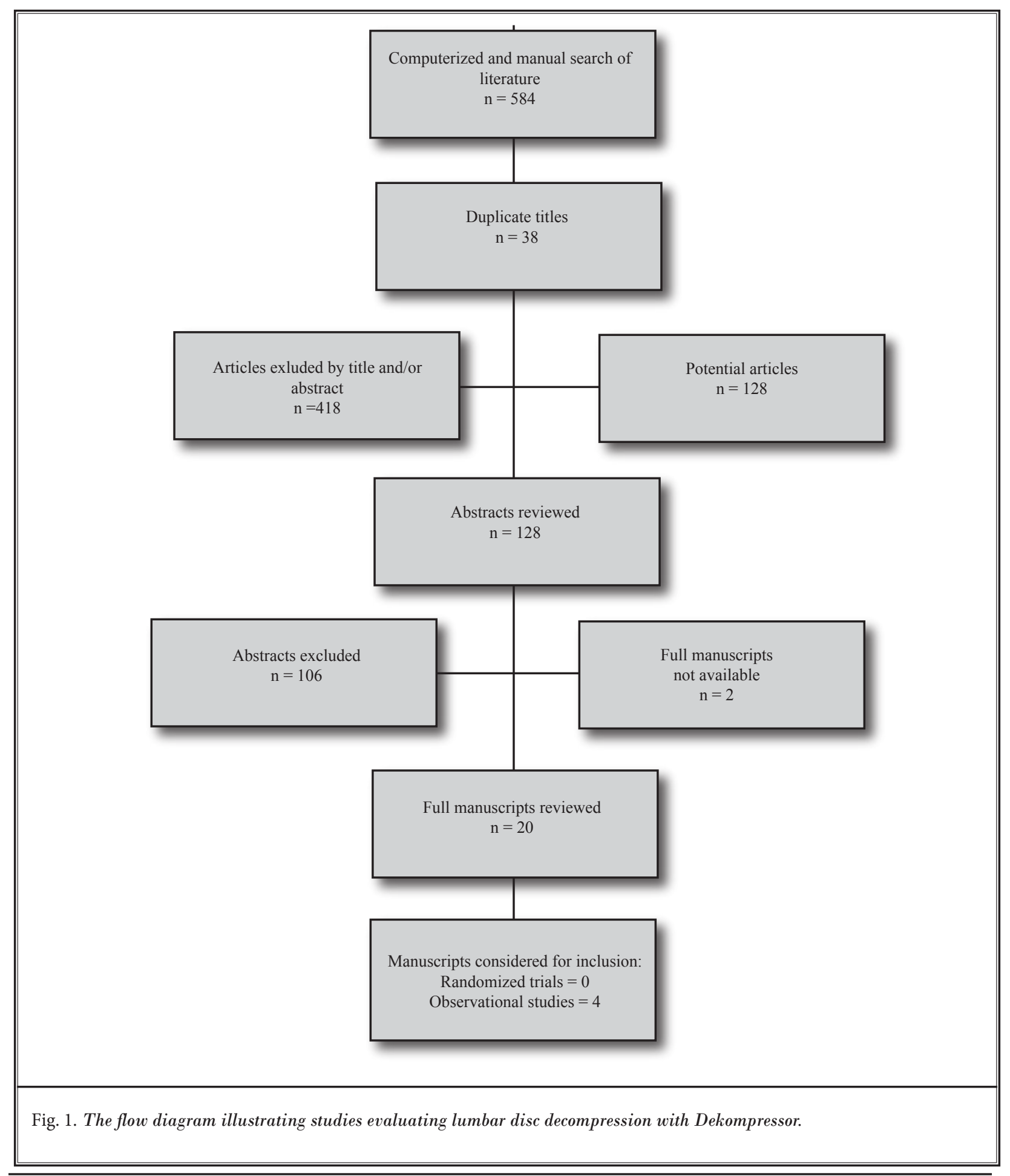


provided 6-month follow-up only. Thus, 2 studies met inclusion criteria $(8,9)$.
Methodologic quality assessment was conducted on these 2 studies as shown in Table 3.

Table 3. Methodological assessment of observational studies evaluating lumbar disc decompression with Dekompressor.

\begin{tabular}{|c|c|c|c|}
\hline CRITERION & $\begin{array}{l}\text { Weighted Score } \\
\text { (points) }\end{array}$ & $\begin{array}{l}\text { Alo et al } \\
\text { (8) }\end{array}$ & $\begin{array}{l}\text { Lierz et al } \\
\text { (9) }\end{array}$ \\
\hline 1. Study Question & 2 & 2 & 2 \\
\hline \multicolumn{4}{|l|}{ - Clearly focused and appropriate question } \\
\hline 2. Study Population & 8 & 5 & 5 \\
\hline - Description of study population & 5 & 5 & 5 \\
\hline - Sample size justification & 3 & - & - \\
\hline 3. Comparability of Subjects & 22 & 11 & 11 \\
\hline - Specific inclusion/exclusion criteria for all groups & 5 & 5 & 5 \\
\hline - Criteria applied equally to all groups & 3 & 3 & 3 \\
\hline - Comparability of groups at baseline with regard to disease status and prognostic factors & 3 & - & - \\
\hline - Study groups comparable to non-participants with regard to confounding factors & 3 & 3 & 3 \\
\hline - Use of concurrent controls & 5 & - & - \\
\hline - Comparability of follow-up among groups at each assessment & 3 & - & - \\
\hline 4. Exposure or Intervention & 11 & 8 & 8 \\
\hline - Clear definition of exposure & 5 & 5 & 5 \\
\hline - Measurement method standard, valid and reliable & 3 & 3 & 3 \\
\hline - Exposure measured equally in all study groups & 3 & - & - \\
\hline 5. Outcome measures & 20 & 8 & 8 \\
\hline - Primary/secondary outcomes clearly defined & 5 & 3 & 3 \\
\hline - Outcomes assessed blind to exposure or intervention & 5 & - & - \\
\hline - Method of outcome assessment standard, valid and reliable & 5 & 2 & 2 \\
\hline - Length of follow-up adequate for question & 5 & 3 & 3 \\
\hline 6. Statistical Analysis & 19 & 8 & 8 \\
\hline - Statistical tests appropriate & 5 & 5 & 5 \\
\hline - Multiple comparisons taken into consideration & 3 & 3 & 3 \\
\hline - Modeling and multivariate techniques appropriate & 2 & - & - \\
\hline - Power calculation provided & 2 & - & - \\
\hline - Assessment of confounding & 5 & - & - \\
\hline - Dose-response assessment if appropriate & 2 & - & - \\
\hline 7. Results & 8 & 5 & 5 \\
\hline - Measure of effect for outcomes and appropriate measure of precision & 5 & 3 & 3 \\
\hline - Adequacy of follow-up for each study group & 3 & 2 & 2 \\
\hline 8. Discussion & 5 & 5 & 5 \\
\hline \multicolumn{4}{|l|}{$\begin{array}{l}\text { - Conclusions supported by results with possible biases and limitations taken into } \\
\text { consideration }\end{array}$} \\
\hline 9. Funding or Sponsorship & 5 & 0 & 0 \\
\hline \multicolumn{4}{|l|}{ - Type and sources of support for study } \\
\hline TOTAL SCORE= & 100 & 52 & 52 \\
\hline
\end{tabular}

Adapted and modified from West S et al. Systems to Rate the Strength of Scientific Evidence, Evidence Report, Technology Assessment No. 47. AHRQ Publication No. 02-E016 (35). 


\section{Descriptive Characteristics}

There were no systematic reviews or randomized trials available for review for management of disc herniation with the Dekompressor. Relevant literature included 3 publications $(8,9,67)$, with 2 studies $(8,9)$ meeting inclusion criteria. Table 4 illustrates results of published evaluations meeting inclusion criteria.

Alo et al $(7,8)$ published the findings on the outcome of disc herniations treated with the Dekompressor in 2 publications from one study. Clinical response in an initial cohort of 50 consecutive patients with chronic radicular pain was evaluated in a randomized prospective clinical trial. Data was collected on the 6month outcomes. Their inclusion criteria were radicular pain with contained herniation $\leq 6 \mathrm{~mm}$., correlating history and physical findings, pain for $>6$ months, failure of conservative therapies, good to excellent short-term relief (< 2 weeks) after a fluoroscopically guided transforaminal injection, confirmatory selective segmental spinal nerve block with $0.5-1.5 \mathrm{~mL}$ of anesthetic providing $>80 \%$ relief lasting at least the duration of the local anesthetic, and preservation of disc height ( $<50 \%$ loss). They excluded patients with progressive neurological deficits, more than 2 symptomatic levels, previous open surgery at the proposed treatment level, spine instability, fracture or tumor, pain drawing inconsistent with clinical diagnosis, and significant coexisting medical or psychological condition. They assessed the outcome using VAS score, analgesic usage, self-reported functional improvement, and overall satisfaction. It may have been more objective had they utilized some form of functional improvement measure. After 6 months, 74\% patients reported reducing their analgesic intake, 90\% reported improvement in functional status, and overall satisfaction with the therapy was $80 \%$. After 1-year followup, the data was published on 42 patients (54 levels). They noted an average reduction in pre-operative pain score (VAS) of $65 \%$. Also noted was a reduction in the analgesic intake in $79 \%$ and functional improvement in $91 \%$ of patients.

Lierz et al (9) evaluated percutaneous lumbar discectomy using the Dekompressor system under CT guidance. They evaluated 64 patients with discectomy at 76 lumbar levels. Follow-up data after 12 months were obtained for all patients. The average reported pain level as measured by VAS was 7.3 before the procedure and 2.1 after 12 months. Before the procedure, 61 patients $(95 \%)$ used opioid or non-opioid analgesics regularly; after one-year a reduction in analgesic use was seen in 51 patients $(80 \%)$. None of the patients reported procedure-related complications. They concluded that when standardized patient selection criteria is used, treatment of patients with radicular pain associated with contained disc herniation using the Dekompressor can be a safe and efficient procedure.

Amoretti et al (67) published results of a clinical follow-up of 50 patients treated by percutaneous lumbar discectomy using the Dekompressor. Although it is not a blinded and randomized study, the data collection was thought to be good. There was clearly define inclusion and exclusion criteria. They included patients with "lumbar sciatica of disco-lumbar origin" secondary to a herniated disc documented by an MRI. Patients had undergone medical therapies such as "CT-guided infiltration" which one assumes to be a corticosteroid injection. There was no change in disc height and the discs possessed satisfactory hydration as documented by a T2 signal on MRI. They excluded patients with extruded herniations and inconsistency between MRI and clinical findings as well as other common exclusions like infection and coagulopathy. Patients being medically treated with morphine and anti-inflammatory drugs pre-operatively were also excluded from the study. Using a Dekompressor instrument under CT or fluoroscopic guidance, they performed disc decompression on mainly L4-5 and L5-S1 discs with some L3-4 discs. They found that 11

Table 4. Results of published studies of Dekompressor meeting inclusion criteria.

\begin{tabular}{|l|c|c|c|c|c|c|c||}
\hline \multirow{2}{*}{ Study } & & & \multicolumn{2}{|c|}{ Pain relief } & \multicolumn{2}{|c|}{ Results } \\
\cline { 5 - 9 } & Characteristics & $\begin{array}{c}\text { Methodological } \\
\text { Quality Score }\end{array}$ & $\begin{array}{c}\text { No. of } \\
\text { patients }\end{array}$ & $\mathbf{6 ~ m o s}$ & $\mathbf{1}$ year & $\begin{array}{c}\text { Short-term } \\
\text { relief } \leq \mathbf{1} \text { year }\end{array}$ & $\begin{array}{c}\text { Long-term } \\
\text { relief } \\
\mathbf{1} \text { year }\end{array}$ \\
\hline Alo et al (8) & $\mathrm{O}$ & 52 & 50 & $74 \%$ & $65 \%$ & $\mathrm{P}$ & $\mathrm{P}$ \\
\hline Lierz et al (9) & $\mathrm{O}$ & 52 & 64 & $80 \%$ & $80 \%$ & $\mathrm{P}$ & $\mathrm{P}$ \\
\hline
\end{tabular}

$\mathrm{O}=$ Observational; $\mathrm{P}=$ positive 
patients did not respond satisfactorily to the treatment, but 39 patient were either able to suspend their medications (31 patients) or definitely reduce their medications (8 patients). The reduction in pain was found to be stabilized after about 7 days in most patients. Of the ones who responded favorably, 36 out of 50 showed $>70 \%$ relief. More importantly they noted $>70 \%$ improvement in $79 \%$ pf patients with postero-lateral hernias versus $50 \%$ of patients with postero-medial hernias. However, this study failed to meet inclusion criteria as the follow-up was limited to 6 months only.

\section{Complications and Side Effects}

One critical failure of the Dekompressor probe was reported while performing a discectomy at $L 4 / 5$ level on a 54-year-old patient (68). After operating the instrument for one to 2 minutes, the probe was removed and it was found to be broken. The remaining 4-inch tip was removed surgically, and the patient recovered without any major complication. Similar instances have been reported by 2 other authors in the past. One of the instances was thought to have happened because of a bent cannula which may have contributed to the break of the device.

\section{Level of Evidence}

Based on United States Preventive Services Task Force (USPSTF) criteria (65), the indicated evidence for Dekompressor is Level III for short- and long-term relief.

\section{Recommendations}

Based on Guyatt et al's (66) criteria, the recommendation for Dekompressor is $2 \mathrm{C} /$ very weak.

\section{Discussion}

This systematic review evaluated the role of lumbar disc decompression with mechanical high RPM device or Dekompressor which indicated Level III evidence based on USPSTF criteria (65) for short- and long-term relief with a $2 \mathrm{C} /$ very weak recommendation based on Guyatt et al's (68) criteria.

The evidence is in contrast to Level II-2 for APLD (29) and laser discectomy (31) and II-3 for nucleoplasty (33). APLD and laser discectomy provide extensive clinical outcome results, whereas nucleoplasty was evaluated in 5 studies. In contrast, the present systematic review for the Dekompressor included only 2 small observational studies, with methodologic quality assessment criteria barely meeting the cutoff (52 out of 100) for evidence synthesis. Consequently, while all minimally invasive techniques need proof of their efficacy, the Dekompressor is in a nascent stage.

The device removes a predetermined amount of disc material from the herniated disc, reducing pressure in the disc and the surrounding area. Less perineural scaring and post-operative fibrosis may be expected using a cannula placement similar to that used for a standard discography. However, epidural fibrosis may also develop with minimally invasive techniques (69). Among the claimed major advantages of the new Dekompressor system is low diameter of the cannula, minimizing the risk of injury at disc insertion (9). Proponents of the Dekompressor claim that unlike other available systems, the device removes material from the disc in a fashion that can be quantified and examined histologically. However, this is not significantly different from automated percutaneous lumbar discectomy or APLD, which is performed with a pneumatically driven, suction-cutting probe in a cannula with a $2.8 \mathrm{~mm}$ outer diameter except for the size. In both techniques the disc is removed to decompress the nerve roots and this can be examined externally, however, with either technique currently there are no specific recommendations. The authors also claim that because of the fast and gentle procedure, it is possible to treat multiple levels of the lumbar spine at the same time, specifically under CT control (9). However, proponents (9) also showed that patients with multiple-treated levels showed less benefit in various outcome parameters. Consequently, the selection of patients with specific indications is crucial for this procedure which is similar to other procedures. Further, the best results may be obtained when the disc herniation is contained and is limited to a single level.

In spite of the lack of evidence, the Dekompressor is appealing because it is simple, relatively safe, and destroys minimal tissue. Consequently, disc height should therefore be maintained or collapse more slowly and allowing the body time to adapt. The Dekompressor may be considered prior to open discectomy for patients with leg pain and a contained disc herniation. However, automated percutaneous lumbar discectomy and laser discectomy have been shown to have better evidence with extensive experience $(29,31)$.

The limitations of this systematic review include a lack of literature and lack of wide application. 


\section{Conclusion}

This systematic review illustrates Level II-3 evidence with $2 \mathrm{C} /$ weak recommendation. However, the Dekompressor may be a useful modality in carefully selected patients with contained disc herniations.

\section{Acknowledgments}

The authors wish to thank the editorial board of Pain Physician for review and criticism in improving the manuscript; Sekar Edem for assistance in search of literature; and Tonie M. Hatton and Diane E. Neihoff, transcriptionists (Pain Management Center of Paducah), for their assistance in preparation of this manuscript.

\section{References}

1. Gibson JNA, Waddell G. Surgical interventions for lumbar disc prolapse. Cochrane Database Syst Rev 2009; (1): CDoo1350.

2. Mixter W, Barr J. Rupture of the intervertebral disc with involvement of the spinal canal. N Engl J Med 1934; 211:210215.

3. Love JG. Removal of the protruded intervertebral discs without laminectomy [editorial]. Proc Mayo Clin 1939; 14:1800.

4. Smith L. Enzyme dissolution of the nucleus pulposus in humans. JAMA 1964; 187:137-140.

5. Hijikata S. Percutaneous nuclectomy: A method of percutaneous nuclear extraction. J Toden Hospital 1975; 5:39-44.

6. Onik G, Helms C, Ginsburg L, Hoaglund FT, Morris J. Percutaneous lumbar diskectomy using a new aspiration probe. AJNR 1985; 6:290-293.

7. Alo KM, Wright RE, Sutcliffe J, Brandt SA. Percutaneous lumbar discectomy: Clinical response in an initial cohort of fifty consecutive patients with chronic radicular pain. Pain Pract 2004; 4:1929.

8. Alo KM, Wright RE, Sutcliffe J, Brandt SA. Percutaneous lumbar discectomy: Oneyear follow-up in an initial cohort of fifty consecutive patients with chronic radicular pain. Pain Pract 2005; 5:116-124.

9. Lierz P, Alo KM, Felleiter P. Percutaneous lumbar discectomy using the Dekompressor System under CT-control. Pain Pract 2009; 9:216-220.

10. Percutaneous Discectomy. Washington State Department of Labor and Industries, Office of Medical Director; February 24, 2004.

11. Kloth DS, Singh V, Manchikanti L. Percutaneous mechanical disc decompression. In Manchikanti L, Singh V (eds). Interventional Techniques in Chronic Spi- nal Pain,.ASIPP Publishing, Paducah, KY 2007; pp 601-622.

12. Phurrough S, Salive M, O'Connor D, Schafer J. Decision Memo for Thermal Intradiscal Procedures. 2008 [cited September 30, 2008]. www.cms.hhs.gov/ $\mathrm{mcd} /$ viewdecisionmemo.asp?from $2=v i$ ewdecisionmemo. asp\&id $=215$ \&

13. Manchikanti L. Medicare in interventional pain management: A critical analysis. Pain Physician 2006; 9:171-198.

14. Manchikanti $L$. The growth of interventional pain management in the new millennium: A critical analysis of utilization in the Medicare population. Pain Physician 2004; 7:465-482.

15. Deyo RA, Gray DT, Kreuter W, Mirza S, Martin BI. United States trends in lumbar fusion surgery for degenerative conditions. Spine 2005; 30:1441-1445.

16. Manchikanti L, Boswell MV. Interventional techniques in ambulatory surgical centers: A look at the new payment system. Pain Physician 2007; 10:627650.

17. Boswell MV, Trescot AM, Datta S, Schultz DM, Hansen HC, Abdi S, Sehgal N, Shah RV, Singh V, Benyamin RM, Patel VB, Buenaventura RM, Colson JD, Cordner HJ, Epter RS, Jasper JF, Dunbar EE, Atluri SL, Bowman RC, Deer TR, Hansen HC, Staats PS, Smith HS, Burton AW, Kloth DS, Giordano J, Manchikanti L. Interventional techniques: Evidencebased practice guidelines in the management of chronic spinal pain. Pain Physician 2007; 10:7-111.

18. Manchikanti L, Giordano J. Physician payment 2008 for interventionalists: Current state of health care policy. Pain Physician 2007; 10:607-626.

19. Manchikanti L, Singh V, Pampati V, Smith HS, Hirsch JA. Analysis of growth in interventional techniques in managing chronic pain in Medicare popula- tion: A 10-year evaluation from 1997 to 2006. Pain Physician 2009; 12:9-34.

20. Gibson JN, Grant IC, Waddell G. The Cochrane review of surgery for lumbar disc prolapse and degenerative lumbar spondylosis. Spine 1999; 24:18201832.

21. Gibson JN, Waddell G. Surgical interventions for lumbar disc prolapse: Updated Cochrane review. Spine 2007; 32:1735-1747.

22. Dewing CB, Provencher MT, Riffenburgh RH, Kerr S, Manos RE. The outcomes of lumbar microdiscectomy in a young, active population: Correlation by herniation type and level. Spine 2008; 33:33-38.

23. Carragee EJ, Han MY, Suen PW, Kim D. Clinical outcomes after lumbar discectomy for sciatica: The effects of fragment type and anular competence. J Bone Joint Surg Am 2003; 85:102-108.

24. Carragee EJ, Kim DH. A prospective analysis of magnetic resonance imaging findings in patients with sciatica and lumbar disc herniation. Correlation of outcomes with disc fragment and canal morphology. Spine 1997; 22:16501660.

25. Nordby EJ, Wright PH, Schofield SR. Safety of chemonucleolysis: Adverse effects reported in the United States, 1982-1991. Clin Orthop 1993; 293:122134.

26. Melrose J, Taylor TK, Ghosh P, Holbert C, Macpherson C, Bellenger CR. Intervertebral disc reconstitution after chemonucleolysis with chymopapain is dependent on dosage. Spine 1996; 21:917.

27. Dullerud R, Amundsen T, Lie H, Juel NG, Abdelnoor M, Magnaes B. Clinical results after percutaneous lumbar nucleotomy. A follow-up study. Acta Radiol 
1995; 36:418-424.

28. Postacchini F. Management of herniation of the lumbar disc. J Bone Joint Surg Br 1999; 81:567-576.

29. Hirsch JA, Manchikanti L, Singh V, Benyamin RM, Derby R. Automated percutaneous lumbar discectomy for the contained herniated lumbar disc: A systematic assessment of evidence. Pain Physician 2009; 12:601-620.

30. Rheinhard SWR, Kraemer J. Chemonucleolysis versus laser disc decompression: A prospective randomized trial. J Bone Joint Surg Br 1997; 79:247.

31. Singh V, Manchikanti L, Benyamin RM, Helm S, Derby R, Hirsch JA. Percutaneous lumbar laser disc decompression: A systematic review of current evidence. Pain Physician 2009; 12:573588.

32. Eggers PE. Coblation: A newly described method for soft tissue surgery. Res Out in Arth Surg 1997; 2:1-4.

33. Manchikanti L, Derby R, Benyamin RM, Helm S, Hirsch JA. A systematic review of mechanical disc decompression with nucleoplasty. Pain Physician 2009; 12:561-572.

34. Koes BW, Scholten RJ, Mens JMA, Bouter LM. Efficacy of epidural steroid injections for low-back pain and sciatica: A systematic review of randomized clinical trials. Pain 1995; 63:279-288.

35. West S, King V, Carey TS, Lohr KN, McKoy N, Sutton SF, Lux L. Systems to Rate the Strength of Scientific Evidence, Evidence Report, Technology Assessment No. 47. AHRQ Publication No. 02E016. Rockville, MD: Agency for Healthcare Research and Quality, 2002. www. thecre.com/pdf/ahrq-system-strength. pdf

36. Manchikanti L, Singh V, Derby R, Schultz DM, Benyamin RM, Prager JP, Hirsch JA. Reassessment of evidence synthesis of occupational medicine practice guidelines for interventional pain management. Pain Physician 2008; 11:393482.

37. Atluri S, Datta S, Falco FJ, Lee M. Systematic review of diagnostic utility and therapeutic effectiveness of thoracic facet joint interventions. Pain Physician 2008; 11:611-629.

38. Conn A, Buenaventura R, Datta S, Abdi S, Diwan S. Systematic review of caudal epidurals injections in the management of chronic low back pain. Pain Physician 2009; 12:109-135.

39. Parr AT, Diwan S, Abdi S. Lumbar inter- laminar epidural injections in managing chronic low back and lower extremity pain: A systematic review. Pain Physician 2009; 12:163-188.

40. Buenaventura R, Datta S, Abdi S, Smith HS. Systematic review of therapeutic lumbar transforaminal epidural steroid injections. Pain Physician 2009; 12:233-251.

41. Benyamin R., Singh V, Parr AT, Conn A, Diwan S, Abdi S. Systematic review of the effectiveness of cervical epidurals in the management of chronic neck pain. Pain Physician 2009; 12:137-157.

42. Helm S, Hayek SM, Benyamin RM, Manchikanti L. Systematic review of the effectiveness of thermal annular procedures in treating discogenic low back pain. Pain Physician 2009; 12:207-232.

43. Falco FJE, Erhart S, Wargo BW, Bryce DA, Atluri S, Datta S, Hayek SM. Systematic review of diagnostic utility and therapeutic effectiveness of cervical facet joint interventions. Pain Physician 2009; 12:323-344.

44. Datta S, Lee M, Falco FJE, Bryce DA, Hayek SM. Systematic assessment of diagnostic accuracy and therapeutic utility of lumbar facet joint interventions. Pain Physician 2009; 12:437460.

45. Epter RS, Helm S, Hayek SM, Benyamin RM, Smith HS, Abdi S. Systematic review of percutaneous adhesiolysis and management of chronic low back pain in post lumbar surgery syndrome. Pain Physician 2009; 12:361-378.

46. Hayek SM, Helm S, Benyamin RM, Singh V, Bryce DA, Smith HS. Effectiveness of spinal endoscopic adhesiolysis in post lumbar surgery syndrome: A systematic review. Pain Physician 2009; 12:419-435.

47. Frey ME, Manchikanti L, Benyamin RM, Schultz DM, Smith HS, Cohen SP. Spinal cord stimulation for patients with failed back surgery syndrome: A systematic review. Pain Physician 2009; 12:379-397.

48. Patel VB, Manchikanti L, Singh V, Schultz DM, Hayek SM, Smith HS. Systematic review of intrathecal infusion systems for long-term management of chronic non-cancer pain. Pain Physician 2009; 12:345-360.

49. Rupert MP, Lee M, Manchikanti L, Datta S, Cohen SP. Evaluation of sacroiliac joint interventions: A systematic appraisal of the literature. Pain Physician 2009; 12:399-418.
50. Manchikanti L, Boswell MV, Giordano J. Evidence-based interventional pain management: Principles, problems, potential, and applications. Pain Physician 2007; 10:329-356.

51. Manchikanti L. Evidence-based medicine, systematic reviews, and guidelines in interventional pain management: Part 1: Introduction and general considerations. Pain Physician 2008; 11:161-186.

52. Manchikanti L, Hirsch JA, Smith HS. Evidence-based medicine, systematic reviews, and guidelines in interventional pain management: Part 2: Randomized controlled trials. Pain Physician 2008; 11:713-775.

53. Manchikanti L, Benyamin RM, Helm S, Hirsch JA. Evidence-based medicine, systematic reviews, and guidelines in interventional pain management: Part 3: Systematic reviews and meta-analysis of randomized trials. Pain Physician 2009; 12:35-72.

54. Manchikanti L, Singh V, Smith HS, Hirsch JA. Evidence-based medicine, systematic reviews, and guidelines in interventional pain management: Part 4: Observational studies. Pain Physician 2009; 12:73-108.

55. Salaffi F, Stancati A, Silvestri CA, Ciapetti A, Grassi W. Minimal clinically important changes in chronic musculoskeletal pain intensity measured on a numerical rating scale. Eur J Pain 2004; 8:283-291.

56. Farrar JT, Young JP Jr, LaMoreaux L, Werth JL, Poole RM. Clinical importance of changes in chronic pain intensity measured on an 11-point numerical pain rating scale. Pain 2001; 94:149158.

57. Bombardier C. Outcome assessments in the evaluation of treatment of spinal disorders: Summary and general recommendations. Spine 2000; 25:31003103.

58. Manchikanti L, Singh V, Falco FJE, Cash KA, Pampati V. Effectiveness of thoracic medial branch blocks in managing chronic pain: A preliminary report of a randomized, double-blind controlled trial: Clinical trial NCTo0355706. Pain Physician 2008; 11:491-504.

59. Manchikanti L, Singh V, Falco FJ, Cash KA, Fellows B. Cervical medial branch blocks for chronic cervical facet joint pain: A randomized double-blind, controlled trial with one-year follow-up. Spine 2008; 33:1813-1820.

6o. Manchikanti L, Singh V, Falco FJ, Cash 
KA, Pampati V. Lumbar facet joint nerve blocks in managing chronic facet joint pain: One-year follow-up of a randomized, double-blind controlled trial: Clinical Trial NCTo0355914. Pain Physician 2008; 11:121-132.

61. Manchikanti L, Cash KA, McManus CD, Pampati V, Smith HS. Preliminary results of randomized, equivalence trial of fluoroscopic caudal epidural injections in managing chronic low back pain: Part 1. Discogenic pain without disc herniation or radiculitis. Pain Physician 2008; 11:785-800.

62. Manchikanti L, Singh V, Cash KA, Pampati V, Damron KS, Boswell MV. Preliminary results of randomized, equivalence trial of fluoroscopic caudal epidural injections in managing chronic low back pain: Part 2. Disc herniation and radiculitis. Pain Physician 2008; 11:801-815.
63. Manchikanti L, Singh V, Cash KA, Pampati V, Datta S. Preliminary results of randomized, equivalence trial of fluoroscopic caudal epidural injections in managing chronic low back pain: Part 3. Post surgery syndrome. Pain Physician 2008; 11:817-831.

64. Manchikanti L, Cash KA, McManus CD, Pampati V, Abdi S. Preliminary results of randomized, equivalence trial of fluoroscopic caudal epidural injections in managing chronic low back pain: Part 4. Spinal stenosis. Pain Physician 2008; 11:833-848.

65. Berg AO, Allan JD. Introducing the third U.S. Preventive Services Task Force. Am J Prev Med 2001; 20:S3-S4.

66. Guyatt G, Gutterman D, Baumann $\mathrm{MH}$, Addrizzo-Harris D, Hylek EM, Phillips $B$, Raskob G, Lewis SZ, Schünemann $H$. Grading strength of recommenda- tions and quality of evidence in clinical guidelines. Report from an American College of Chest Physicians Task Force. Chest 2006; 129:174-181.

67. Amoretti N, David P, Grimaud A, Flory P, Hovorka I, Roux C, Chevallier P, Bruneton JN. Clinical follow-up of 50 patients treated by percutaneous lumbar discectomy. Clin Imaging 2006; 30:242244 .

68. Domsky R, Goldberg M, Hirsh RA, Scaringe D, Torjman MC. Critical failure of a percutaneous discectomy probe requiring surgical removal during disc decompression. Reg Anesth Pain Med 2006; 31:177-179.

69. Smuck M, Benny B, Han A, Levin J. Epidural fibrosis following percutaneous disc decompression with coblation technology. Pain Physician 2007; 10:691-696. 
